\title{
MEASUREMENT OF RADON EXHALATION RATE, RADIUM ACTIVITY AND ANNUAL EFFECTIVE DOSE FROM BRICKS AND CEMENT SAMPLES COLLECTED FROM DERA ISMAIL KHAN
}

\author{
${ }^{1}$ Nisar Ahmad, ${ }^{1}$ Mohamad Suhaimi Jaafar, ${ }^{1}$ Sohail Aziz Khan, \\ ${ }^{2}$ Tabassum Nasir, ${ }^{2}$ Sajjad Ahmad and ${ }^{3}$ Muhammad Rahim \\ ${ }^{1}$ School of Physics, Universiti Sains Malaysia, 11800, Pulau Pinang, Malaysia \\ ${ }^{2}$ Department of Physics, Gomel University Dera Ismail Khan, Pakistan \\ ${ }^{3}$ School of Chemical Sciences, Universiti Sains Malaysia, 11800, Pulau Pinang, Malaysia
}

Received 2013-11-14; Revised 2013-11-18; Accepted 2013-12-21

\begin{abstract}
Radon concentration, exhalation rate, radium activity and annual effective dose have been measured from baked and unbaked bricks and cement samples commonly used as construction material in the dwellings of Dera Ismail Khan City, Pakistan. CR-39 based NRPB radon dosimeters and RAD7 have been used as passive and active devises. The values of radon concentration for baked, unbaked bricks and cements obtained from passive and active techniques were found in good agreement. Average values of radon exhalation rates in baked, unbaked bricks and cement were found (1.202 \pm 0.212$) \mathrm{Bq} \mathrm{m}^{-2} \mathrm{~h}^{-1}$, $(1.419 \pm 0.230) \mathrm{Bq} \mathrm{m}^{-2} \mathrm{~h}^{-1}$ and $(0.386 \pm 0.117) \mathrm{Bq} \mathrm{m}^{-2} \mathrm{~h}^{-1}$ and their corresponding average radium activity and annual effective dose were found $(0.956 \pm 0.169) \mathrm{Bq} / \mathrm{kg},(1.13 \pm 0.184) \mathrm{Bq} / \mathrm{kg},(0.323 \pm 0.098) \mathrm{Bq} / \mathrm{kg}$ and $(33.96 \pm 5.99) \mu \mathrm{Sv} \mathrm{y}{ }^{-1}$, (40.3 \pm 6.51$) \mu \mathrm{Sv} \mathrm{y}^{-1}$ and $(10.94 \pm 3.28) \mu \mathrm{Sv} \mathrm{y}^{-1}$, respectively. Radon concentration, exhalation rate and their corresponding radium activity and annual effective dose were found higher in unbaked bricks as compared to baked bricks and cement but overall values of radon exhalation rate, annual effective dose and radium activity were found well below the world average values of $57.600 \mathrm{~Bq} \mathrm{~m}^{-2} \mathrm{~h}^{-1}, 1100 \mu \mathrm{Sv} \mathrm{y}{ }^{-1}$ and $370 \mathrm{~Bq} / \mathrm{kg}$, respectively.
\end{abstract}

Keywords: Radon, CR-39, NRPB Dosimeter, RAD7

\section{INTRODUCTION}

High concentration of radon and its decay product is widely known to be dangerous to human health. It is possibly associated with different types of cancer and especially with lung cancer. Emission percentage of radon into atmosphere coming from a few meters above the ground is at least $80 \%$ (Shweikani et al., 1995). Radon is a natural radioactive gas which is found everywhere and cannot be avoided. It has very serious effects on human health due to large scale abundance of its parents and its longer half life. Radon has been considered as second leading cause of lung cancer after smoking (IARC, 2004). A $2.4 \mathrm{mSv}$ average annual dose has been estimated from natural radiation sources to the world population. Two-third of average annual dose is the internal exposure and one-third is external exposure (Wang, 2002). Inhalation of radon gas and its daughters will expose the lung tissue to short-lived alpha emitting radio nuclides, which will increase the risk of lung cancer. One of the major factors of increasing skin cancer is radon gas, where it is due to the deposition of radon on the skin, the alpha particles are suspected to include damage to the epithelial cell. Kidney related diseases have also been observed in some people exposed to radon. The reason is that kidney receives the highest dose compared to other body organs, after Corresponding Author: Nisar Ahmad, School of Physics, Universiti Sains Malaysia, 11800, Pulau Pinang, Malaysia 
radon is transferred from the lung to the kidney by blood (Henshaw et al., 1990).

Different sources are responsible for the presence of radon and its daughters in houses. One of the major sources of concentration of radon in houses is the building materials used for construction. Cracks in walls, floors, joints or pipe holes and lines provide a channel for radon which flows to the surface and ultimately enters houses. In addition, the radon production rate in houses depends on the concentrations in the building materials, subsoil, porosity, density of the uranium and radium activity in materials used for construction (Cartwright et al., 1978).

The presence of radon is expected everywhere, but found in high concentration in soil and rocks enriched in radium and uranium elements. Most of these soils and rocks are compacted and processed to produce building materials that are used for workplaces and houses in which we work and live. There are many concerns about the escape of radon from building materials into the workplaces and houses. All nations, including Pakistan, use building materials in workplaces and houses such as cements, granite, tiles, clay, sand, bricks and ceramic. If radon emanated from these materials exceeds the action level of $200 \mathrm{~Bq} \cdot \mathrm{m}^{-3}$, then remedial action should be taken to reduce health hazards due to exposure to indoor radon.

Numerous studies in Pakistan have been conducted to measure radon concentration in air, soil and building materials (Faheem et al., 2010; Nasir and Ahmad, 2012; Nasir and Shah, 2012; Rafique et al., 2011a; 2011b; Rahman et al., 2012). Therefore, the study of radon exhalation from building materials commonly used in Dera Ismail Khan Dwellings is an important step in diminishing indoor radon levels into significantly below the action level.

\section{DETAIL OF SAMPLES}

The main objectives of this study were to measure the radon concentration, radon exhilaration rate, radium contents and annual effective dose from bricks and cements used as building materials in Dera Ismail Khan City, Pakistan. Twenty samples of bricks (both unbaked and baked) were collected from different bricks kilns and five representative samples of cements were collected from different building materials suppliers in Dera Ismail Khan City. The details on the samples collection of cement are given in Table 1 and that of bricks in Table 2. In Table 1 cement samples are given the names of SS-1 to SS-5, while in Table 2 SS-6 to SS-24 are baked bricks and SS-7 to SS-25 are unbaked bricks.
Table 1. Cement samples from various factories

\begin{tabular}{ll}
\hline Sample name & Factory name \\
\hline SS-1 & Maple leaf cement \\
SS-2 & Kohat cement \\
SS-3 & Lucky cement \\
SS-4 & Askari cement \\
SS-5 & Cherrat cement \\
\hline
\end{tabular}

Table 2. Locations of the collected bricks samples from various kilns

\begin{tabular}{|c|c|c|}
\hline Sample name & No. of samples & Location \\
\hline SS-6,7 & 2 & New sarhad bricks \\
\hline SS-8,9 & do & Ahmad khan bricks \\
\hline SS-10,11 & do & Azhar bricks \\
\hline SS-12,13 & do & Baho bricks \\
\hline SS-14,15 & do & Shabarat bricks \\
\hline SS-16,17 & do & Malik sohail bricks \\
\hline SS-18,19 & do & New baho bricks \\
\hline SS-20,21 & do & Malik bricks \\
\hline SS-22,23 & do & Kerri hamad khan bricks \\
\hline SS-24,25 & do & Kerri nawab bricks \\
\hline
\end{tabular}

\section{EXPERIMENTAL TECHNIQUE}

The collected samples were brought to Laboratory of Radiation Physics, Gomal University Dera Ismail Khan and were dried in oven at $110^{\circ} \mathrm{C}$ for $24 \mathrm{~h}$ to evaporate all the moisture contents. Bricks samples were crushed and homogenized by passing through sieve. After processing samples of $500 \mathrm{~g}$ each of bricks and cement, they were placed in plastic containers of $27.5 \mathrm{~cm}$ in height (volume $9.66 \times 10^{-3} \mathrm{~m}^{3}$ ) with sample surface area $0.03696 \mathrm{~m}^{2}$ (Fig. 1b). The thickness of bricks in the containers was $1.6 \mathrm{~cm}$ and that of cement was 1.5 $\mathrm{cm}$. CR-39 based NRPB radon dosimeters were fitted at a distance of $25 \mathrm{~cm}$ from the surface of the samples in these containers, so as to account only the radon contribution and to avoid the role of thoron from the surface of sample (Howarth et al., 2002). The containers were hermetically sealed for 30 days. About $98 \%$ of equilibrium level is reached between radium and radon during this time period. This resulted in the exposure of the radon to variable levels of radon concentration (i.e., starting from zero concentration level to equilibrium level). Therefore, effective exposure time was calculated by using the following relation (Durrani and Ilic, 1997):

$\mathrm{T}_{\text {effective }}=\mathrm{t}^{-\tau\left(1-\mathrm{e}^{-\lambda \mathrm{t}}\right)}$

Where:

$\tau=$ Mean life of radon (5.5 days)

$\mathrm{t}=$ Total exposure length (30 days)

$\lambda=$ Decay constant of radon $\left(7.55 \times 10^{-3} \mathrm{~h}^{-1}\right)$ 


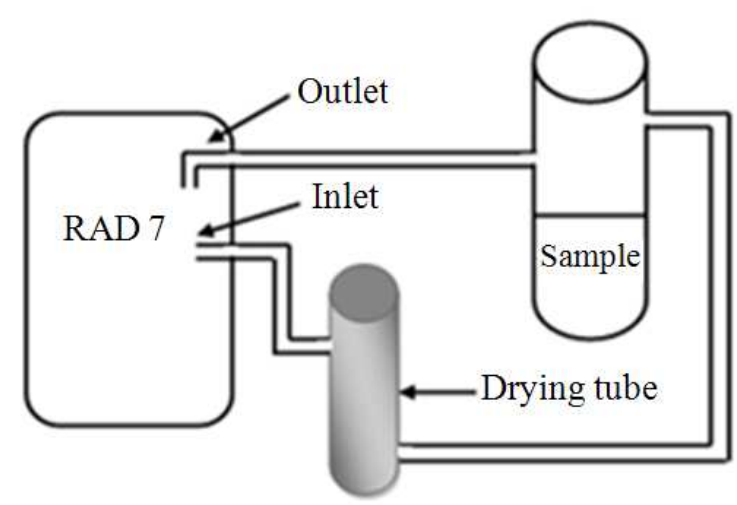

Active technique

(a)

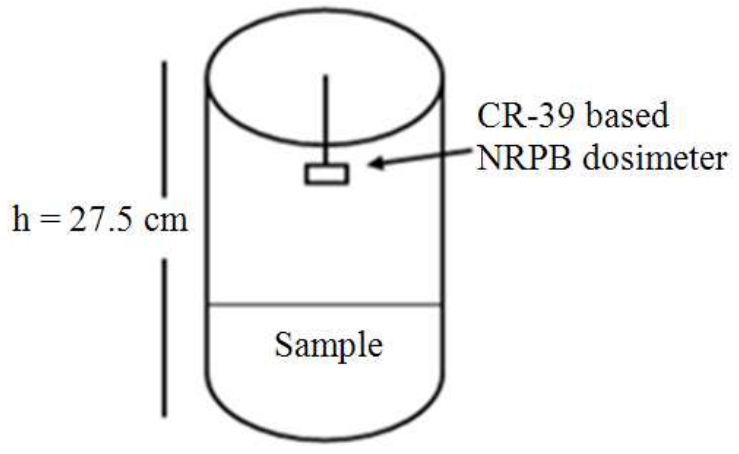

Passive technique

(b)

Fig. 1. Building materials samples under exposure of (a) RAD7 and (b) CR-39 NTDs

This type of correlation is needed only for closed system. The effective time calculated from Equation (1) was $588.575 \mathrm{~h}$.

After the exposure, CR-39 detectors were etched in $6 \mathrm{~N} \mathrm{NaOH}$ at $70^{\circ} \mathrm{C}$ for $8 \mathrm{~h}$ and studied under optical microscope at $400 \times$ magnification.

The track densities were measured using the following Equation (2):

$$
\rho=\frac{\sum_{i} N_{i}}{n A}
$$

Where:

$A=$ The area of field of view, $N_{i}$ is the total number of tracks and

$\mathrm{n} \quad=$ The total number of field of views

The statistical error was calculated using Equation (3):

$$
\sigma_{\rho}=\frac{\sqrt{\Sigma N_{i}}}{n A}
$$

To obtain the track production rate, the measured track density was divided by effective time ( $588.575 \mathrm{~h})$.

The track density was converted into radon concentration using calibration factor (Howarth et al., 2002):

$$
2.7 \mathrm{track} / \mathrm{cm}^{2} \mathrm{~h}=1 \mathrm{kBq} / \mathrm{m}^{3}
$$

Radon exhalation rate was measured for each sample by using Equation (4) (Rafique et al., 2011a):

$$
F_{o}=\frac{C(t)[\omega A+\lambda V]}{\left[1-e^{-\left(\frac{\omega A}{V}+\lambda\right) t}\right]}
$$

Where:

$\mathrm{V}=$ The volume of void space in close container $\left(\mathrm{m}^{3}\right)$

A $=$ The surface area of sample $\left(\mathrm{m}^{2}\right)$ and $\mathrm{t}$ is radon accumulation time in closed container

$\omega=$ Back diffusion and

$\mathrm{C}(\mathrm{t})=$ Measurement of radon concentration.

The radium activity of the samples was calculated by using Equation (5) (Somogyi, 1990; Abd-Elzaher, 2012):

$$
\mathrm{C}_{\text {Radium }}=\rho \mathrm{A}_{\mathrm{c}} / \mathrm{KT}_{\mathrm{e}} \mathrm{M}
$$

where, $\rho, \mathrm{h}$ and $\mathrm{A}_{\mathrm{c}}$ are the track density $\left(\operatorname{track} / \mathrm{cm}^{2}\right)$, distance between the detector and sample (m) and area of cross section of container $\left(\mathrm{m}^{2}\right)$, respectively. $\mathrm{K}$ is the sensitivity factor $\left(0.2315\right.$ tracks $\left.\mathrm{cm}^{-2} \mathrm{~d}^{-1}\left(\mathrm{~Bq} / \mathrm{m}^{3}\right)^{-1}\right)$ (Ismail and Jaafar, 2009).

Annul effective dose from the collected samples was calculated by using following relation (Ackers et al., 1984; Khan, 1994):

$\mathrm{D}_{\mathrm{Rn}}=\mathrm{t}_{\mathrm{f}} \mathrm{T}(\mathrm{DCF})\left(\mathrm{S}_{\mathrm{R}} / \mathrm{V}_{\mathrm{R}}\right)\left(1 / \lambda_{\mathrm{v}}\right)\left(0.45-0.15 \lambda_{\mathrm{v}}\right) \sum \mathrm{F}_{0} \mathrm{si}$

where, $t_{\mathrm{f}}$ is the fraction of time a person spent indoor (0.8), $\mathrm{T}$ is total hours in year $(8760 \mathrm{~h} / \mathrm{y}), \mathrm{DFC}$ is dose conversion factor, $\left(9 \mathrm{nSv} \cdot \mathrm{h}^{-1} / \mathrm{Bq} \cdot \mathrm{m}^{-3}\right)$ or $(6 \mathrm{mSv} / \mathrm{WLM})$ (UNSCEAR, 2000). $S_{R} / V_{R}$ is the ratio of surface area to volume $\left(1.5\right.$ to $\left.3.0 \mathrm{~m}^{-1}\right), \lambda_{\mathrm{v}}$ is the constant of ventilation $\left(0.3\right.$ to $\left.1.0 \mathrm{~h}^{-1}\right),\left(0.45-0.15 \lambda_{\mathrm{v}}\right)$ is the dimension less 
equilibrium factor for radon for the ventilation rate in the interval of $0.1-2$ exchanges per hour, $F_{0}$ is radon exhalation rate $\left(\mathrm{Bq} \mathrm{m} \mathrm{m}^{-2} \mathrm{~h}^{-1}\right)$. To estimate the annual effective dose from the building materials, the following constant factors were used: Dimension of room was assumed as a chamber with $\left(6 \times 4 \times 3 \mathrm{~m}^{3}\right.$ i-e., $\left.V=72 \mathrm{~m}^{3}\right)$, using $\mathrm{S}_{\mathrm{R}} / \mathrm{V}_{\mathrm{R}}$ ratio of $1.5 \mathrm{~m}^{-1}$ and typical value of the ventilation rate $\lambda_{v}$ of 1 air changes per hour.

In order to support the results of Passive technique, RAD7 manufactured by Durridge Company USA was used as an active technique at the School of Physics, Universiti Sains Malaysia by making small modification of the design (Fig. 1a).

RAD7 has an air pump and a solid state alpha detector which consists of semiconductor material. Silicon is usually used as semiconductor material which directly converts alpha radiation to an electrical signal. Solid state devices have the ability to distinguish radon from thoron by the emitted alpha particle energy. $\mathrm{Bq} \mathrm{m}^{-3}$ was used as a standard unit in this study.

For the measurement of radon concentration in building materials by RAD7, samples of $300 \mathrm{~g}$ each were placed in a container of $11 \mathrm{~cm}$ in height and 6 $\mathrm{cm}$ in diameter then connected to RAD7 which enables to degas the radon from the sample into closed loop. Before each measurement, RAD7 was purged for ten minutes to reduce the humidity by using laboratory drying unit. Thirty minutes measuring time at Grab protocol was taken for all samples.

\section{RESULTS}

Table 3 shows the results of radon concentrations of bricks (both unbaked and baked) obtained by passive and active techniques. The range of radon concentration obtained by passive and active techniques in unbaked bricks varies from $(0.1588 \pm 0.0300) \mathrm{kBq} \mathrm{m^{-3 }}$ to $(0.3121 \pm 0.0420) \mathrm{kBq} \mathrm{m}^{-3}$ and $(0.128 \pm 0.031) \mathrm{kBq} \mathrm{m}^{-3}$ to $(0.291 \pm 0.042) \mathrm{kBq} \mathrm{m}^{-3}$ respectively, while in case of baked bricks its values varies from $(0.1362 \pm 0.0278) \mathrm{kBq}$ $\mathrm{m}^{-3}$ to $(0.2837 \pm 0.0401) \mathrm{kBq} \mathrm{m}^{-3}$ and $(0.110 \pm 0.021) \mathrm{kBq}$ $\mathrm{m}^{-3}$ to $(0.241 \pm 0.098) \mathrm{kBq} \mathrm{m}^{-3}$, respectively. Table 4 represents the radon exhalation rate from unbaked and baked bricks calculated by Equation (4). As may seen from the table, radon exhalation rate was found to vary from $(1.068 \pm 0.202) \mathrm{Bq} \mathrm{m}^{-2} \mathrm{~h}^{-1}$ to $(2.100 \pm 0.282) \mathrm{Bq} \mathrm{m}^{-2}$ $\mathrm{h}^{-1}$ in the case of unbaked bricks, while for baked bricks, its values varies from $(0.915 \pm 0.187) \mathrm{Bq} \mathrm{m}^{-2} \mathrm{~h}^{-1}$ to (1.909 \pm 0.269$) \mathrm{Bq} \mathrm{m}^{-2} \mathrm{~h}^{-1}$.

Table 5 represents the results of radon concentrations of cement measured by both techniques and radon exhalation rate. Radon concentration measured by passive and active techniques were $(0.0794 \pm 0.0212) \mathrm{kBq} \mathrm{m}^{-3}$ and $(0.065 \pm 0.021) \mathrm{kBq} \mathrm{m}^{-3}$ for white cement, while in the case of gray cement, its values ranged from $(0.0454 \pm 0.0160)$ $\mathrm{kBq} \mathrm{m}^{-3}$ to $(0.0681 \pm 0.0196) \mathrm{kBq} \mathrm{m}^{-3}$ and $(0.040 \pm 0.013)$ $\mathrm{kBq} \mathrm{m}^{-3}$ to $(0.060 \pm 0.020) \mathrm{kBqm}^{-3}$, respectively. For white cement, the value of radon exhalation rate was $(0.511 \pm 0.136) \mathrm{Bq} \mathrm{m}^{-2} \mathrm{~h}^{-1}$, while in the case of gray cement its values were varied from $(0.292 \pm 0.103) \mathrm{Bq} \mathrm{m}^{-2}$ $\mathrm{h}^{-1}$ to $(0.438 \pm 0.126) \mathrm{Bq} \mathrm{m}^{-2} \mathrm{~h}^{-1}$.

Radium activity and annul effective dose from bricks, calculated by Equation (5 and 6), respectively are presented in Table 6. The maximum value of radium activity in unbaked bricks was $(1.676 \pm 0.225) \mathrm{Bq} / \mathrm{kg}$ and the minimum value was $(0.853 \pm 0.161) \mathrm{Bq} / \mathrm{kg}$, while in the case of baked bricks, the maximum value was $(1.524 \pm 0.215) \mathrm{Bq} / \mathrm{kg}$ and the minimum value was $(0.731 \pm 0.149) \mathrm{Bq} / \mathrm{kg}$. Annual effective dose from unbaked and baked bricks vary from $(30.3 \pm 5.7) \mu \mathrm{Sv} \mathrm{y}^{-1}$ to $(59.6 \pm 8.0) \mu \mathrm{Sv} \mathrm{y}^{-1}$ and $(25.9 \pm 5.3) \mu \mathrm{Sv} \mathrm{y}{ }^{-1}$ to $(54.2 \pm 7.6)$ $\mu \mathrm{Sv} \mathrm{y}^{-1}$, respectively. Radium activity and annual effective dose in white cement were $(0.427 \pm 0.114) \mathrm{Bq} / \mathrm{kg}$ and $(14.5 \pm 3.8) \mu \mathrm{Sv} \mathrm{y}^{-1}$ respectively, while for gray cement its values ranged from $(0.244 \pm 0.086) \mathrm{Bq} / \mathrm{kg}$ to $(0.366 \pm 0.105) \mathrm{Bq} / \mathrm{kg}$ and $(8.2 \pm 2.9) \mu \mathrm{Sv} \mathrm{y}^{-1}$ to $(12.4 \pm 3.5)$ $\mu \mathrm{Sv} \mathrm{y}^{-1}$, respectively as given in Table 7 .

Table 3. Radon concentration in baked and unbaked bricks

\begin{tabular}{|c|c|c|c|c|}
\hline Sample name & $\begin{array}{l}\text { Radon concentration } \\
\left(\mathrm{kBq} \mathrm{m}^{-3}\right) \text { (baked) } \\
\text { RAD7 }\end{array}$ & $\begin{array}{l}\text { Radon concentration } \\
\left(\mathrm{kBq} \mathrm{m}^{-3}\right) \text { (baked) } \\
\text { CR-39 NTDs }\end{array}$ & $\begin{array}{l}\text { Radon concentration } \\
\left(\mathrm{kBq} \mathrm{m}^{-3}\right) \text { (unbaked) } \\
\text { RAD7 }\end{array}$ & $\begin{array}{l}\text { Radon concentration } \\
\left(\mathrm{kBq} \mathrm{m}^{-3}\right) \text { (unbaked) } \\
\text { CR-39 NTDs }\end{array}$ \\
\hline $\begin{array}{l}\text { SS-6,7 } \\
\text { S }\end{array}$ & $0.165 \pm 0.036$ & $0.1759 \pm 0.0315$ & $0.204 \pm 0.039$ & $0.1985 \pm 0.0335$ \\
\hline SS-8,9 & $0.147 \pm 0.031$ & $0.1418 \pm 0.0283$ & $0.131 \pm 0.025$ & $0.1700 \pm 0.0318$ \\
\hline SS-10,11 & $0.191 \pm 0.037$ & $0.1872 \pm 0.0326$ & $0.221 \pm 0.037$ & $0.2155 \pm 0.0348$ \\
\hline SS-12,13 & $0.114 \pm 0.028$ & $0.1532 \pm 0.0294$ & $0.153 \pm 0.033$ & $0.2043 \pm 0.0340$ \\
\hline SS-14,15 & $0.189 \pm 0.036$ & $0.2213 \pm 0.0358$ & $0.216 \pm 0.034$ & $0.2497 \pm 0.0376$ \\
\hline SS-16,17 & $0.151 \pm 0.035$ & $0.1475 \pm 0.0289$ & $0.175 \pm 0.034$ & $0.1644 \pm 0.0305$ \\
\hline SS-18,19 & $0.241 \pm 0.098$ & $0.2837 \pm 0.0401$ & $0.291 \pm 0.042$ & $0.3121 \pm 0.0420$ \\
\hline SS-20,21 & $0.110 \pm 0.021$ & $0.1362 \pm 0.0278$ & $0.128 \pm 0.031$ & $0.1588 \pm 0.0300$ \\
\hline SS-22,23 & $0.144 \pm 0.029$ & $0.1418 \pm 0.0283$ & $0.184 \pm 0.040$ & $0.1816 \pm 0.0321$ \\
\hline SS-24,25 & $0.145 \pm 0.030$ & $0.1929 \pm 0.0330$ & $0.265 \pm 0.045$ & $0.2553 \pm 0.0380$ \\
\hline
\end{tabular}


Table 4. Radon exhalation rate in backed and unbaked samples

\begin{tabular}{|c|c|c|}
\hline Sample name & $\begin{array}{l}\text { Radon Exhalation rate } \\
\left(\text { Bq m}^{-2} \mathrm{~h}^{-1}\right) \text { (baked) } \\
\text { CR-39 NTDs }\end{array}$ & 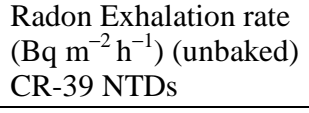 \\
\hline$\overline{S S-6,7}$ & $1.183 \pm 0.212$ & $1.335 \pm 0.225$ \\
\hline SS-8,9 & $0.954 \pm 0.190$ & $1.144 \pm 0.209$ \\
\hline SS-10,11 & $1.259 \pm 0.219$ & $1.450 \pm 0.234$ \\
\hline SS-12,13 & $1.031 \pm 0.197$ & $1.374 \pm 0.228$ \\
\hline SS-14,15 & $1.489 \pm 0.240$ & $1.680 \pm 0.253$ \\
\hline SS-16,17 & $0.992 \pm 0.194$ & $1.106 \pm 0.205$ \\
\hline SS-18,19 & $1.909 \pm 0.269$ & $2.100 \pm 0.282$ \\
\hline SS-20,21 & $0.915 \pm 0.187$ & $1.068 \pm 0.202$ \\
\hline SS-22,23 & $0.993 \pm 0.190$ & $1.222 \pm 0.216$ \\
\hline SS-24,25 & $1.298 \pm 0.222$ & $1.718 \pm 0.255$ \\
\hline
\end{tabular}

$\underline{\text { Table 5. Radon concentration and exhalation rate in cement samples }}$

\begin{tabular}{llll}
\hline & Radon concentration $\left(\mathrm{kBq} \mathrm{m}^{-3}\right)$ & Radon concentration $\left(\mathrm{kBq} \mathrm{m}^{-3}\right)$ & $\begin{array}{l}\text { Exhalation rate }\left(\mathrm{Bq} \mathrm{m}^{-2} \mathrm{~h}^{-1}\right) \\
\text { CR-39 NTDs }\end{array}$ \\
\hline SS-1 & CR-39 NTDs & $0.065 \pm 0.021$ & $0.511 \pm 0.136$ \\
SS-2 & $0.0794 \pm 0.0212$ & $0.040 \pm 0.013$ & $0.292 \pm 0.103$ \\
SS-3 & $0.0454 \pm 0.0160$ & $0.058 \pm 0.019$ & $0.365 \pm 0.115$ \\
SS-4 & $0.0567 \pm 0.0179$ & $0.052 \pm 0.018$ & $0.328 \pm 0.109$ \\
SS-5 & $0.0510 \pm 0.0170$ & $0.060 \pm 0.020$ & $0.438 \pm 0.126$ \\
\hline
\end{tabular}

Table 6. Radium activity and Annual effective dose from baked and unbaked bricks samples

\begin{tabular}{|c|c|c|c|c|}
\hline \multirow[b]{2}{*}{ Sample name } & \multicolumn{4}{|l|}{ CR-39 NTDs } \\
\hline & $\begin{array}{l}\text { Radium activities } \\
(\mathrm{Bq} / \mathrm{kg}) \text { Baked }\end{array}$ & $\begin{array}{l}\text { Radium activities } \\
(\mathrm{Bq} / \mathrm{kg}) \text { unbaked }\end{array}$ & $\begin{array}{l}\text { Annual Effective dose } \\
\left(\mu \mathrm{Sv} \mathrm{y}^{-1}\right) \text { Baked }\end{array}$ & $\begin{array}{l}\text { Annual Effective dose } \\
\left(\mu \mathrm{Sv}^{-1}\right) \text { unbaked }\end{array}$ \\
\hline SS-6,7 & $0.944 \pm 0.169$ & $1.066 \pm 0.180$ & $33.5 \pm 6.0$ & $37.9 \pm 6.3$ \\
\hline SS- 8,9 & $0.761 \pm 0.152$ & $0.914 \pm 0.166$ & $27.0 \pm 5.3$ & $32.4 \pm 5.9$ \\
\hline SS-10,11 & $1.005 \pm 0.175$ & $1.158 \pm 0.187$ & $35.7 \pm 6.28$ & $41.8 \pm 6.6$ \\
\hline SS-12,13 & $0.823 \pm 0.158$ & $1.097 \pm 0.182$ & $29.2 \pm 5.59$ & $39.0 \pm 6.4$ \\
\hline SS-14,15 & $1.188 \pm 0.190$ & $1.341 \pm 0.202$ & $42.2 \pm 6.8$ & $47.7 \pm 7.1$ \\
\hline SS-16,17 & $0.792 \pm 0.155$ & $0.883 \pm 0.163$ & $28.1 \pm 5.5$ & $31.4 \pm 5.8$ \\
\hline SS- 18,19 & $1.524 \pm 0.215$ & $1.676 \pm 0.225$ & $54.2 \pm 7.6$ & $59.6 \pm 8.0$ \\
\hline SS-20,21 & $0.731 \pm 0.149$ & $0.853 \pm 0.161$ & $25.9 \pm 5.3$ & $30.3 \pm 5.7$ \\
\hline SS-22,23 & $0.761 \pm 0.152$ & $0.975 \pm 0.172$ & $27.0 \pm 5.3$ & $34.7 \pm 6.1$ \\
\hline SS-24,25 & $1.036 \pm 0.177$ & $1.371 \pm 0.204$ & $36.8 \pm 6.3$ & $48.7 \pm 7.2$ \\
\hline
\end{tabular}

Table 7. Radium activity and annual effective dose from cements

\begin{tabular}{lll} 
& CR-39 NTDs & \\
Sample name & Radium activities $(\mathrm{Bq} / \mathrm{kg})$ & Annual effective dose $\left(\mu \mathrm{Sv} \mathrm{y}^{-1}\right)$ \\
\hline SS-1 & $0.427 \pm 0.114$ & $14.5 \pm 3.8$ \\
SS-2 & $0.244 \pm 0.086$ & $8.2 \pm 2.9$ \\
SS-3 & $0.305 \pm 0.096$ & $10.3 \pm 3.2$ \\
SS-4 & $0.274 \pm 0.091$ & $9.3 \pm 3.0$ \\
SS-5 & $0.366 \pm 0.105$ & $12.4 \pm 3.5$ \\
\hline
\end{tabular}

\section{DISCUSSION}

Positive and strong correlation has been observed between the results of passive and active techniques. The linear correlation value for both techniques was
0.917, as shown in Fig. 2. The value of the correlation was statistically significant and 99\% confidence interval. Data shown in Table 4 indicate that radon exhalation rate is comparatively higher in unbaked bricks while it is lower in baked bricks. It is due to the 
fact that radon emanation in the case of unbaked bricks can escape from a few centimetres below the surface and the quantity of radon released from materials depends on the internal surface area, while in the case of baked bricks it emanates from the surface layer (Rawat et al., 1991). It can also be seen that radon exhalation rate in these samples varies from sample to sample, which is due to porosity of building materials (Folkerts et al., 1984) and the difference of uranium and radium contents (Ramachandran and Ramu, 1989). The values of white cement were found higher as compared to gray cement. It has been observed form the results that like radon exhalation rate, the values of radium activity and annual effective dose in unbaked bricks are higher than that of baked bricks and cement.
With regards to radon exhalation rate, a large amount of data has been published in literature. Some of these date reported by different researchers in different countries are presented in Table 8. High value of radon exhalation rate $\left(0.11 \mathrm{~Bq} \mathrm{~m} \mathrm{~m}^{-2} \mathrm{~h}^{-1}\right)$ was reported in unbaked bricks and lower value of radon exhalation rate was reported (0.09 $\mathrm{Bq} \mathrm{m}^{-2} \mathrm{~h}^{-1}$ ) in baked bricks in India (Khan, 1994). In the present work, high value of radon exhalation rates were found in unbaked bricks and lower values were found in baked bricks. In Pakistan, (Faheem and Matiullah, 2008) reported radon exhalation rates in Punjab $(0.212 \pm 0.034 \mathrm{~Bq}$ $\left.\mathrm{m}^{-2} \mathrm{~h}^{-1}\right)$ and $\left(0.23 \pm 10.030 \mathrm{~Bq} \mathrm{~m}^{-2} \mathrm{~h}^{-1}\right)$ in bricks and cements, respectively. These values of radon exhalation rate are close to the results of the present study.

Table 8. Comparison of radon exhalation rate of building materials with previous work

\begin{tabular}{|c|c|c|c|c|}
\hline Material & $\begin{array}{l}\text { Present work } \\
\left(\mathrm{Bq} \mathrm{m}^{-2} \mathrm{~h}^{-1}\right)\end{array}$ & $\begin{array}{l}\text { Previous work } \\
\left(\mathrm{Bq} \mathrm{m}^{-2} \mathrm{~h}^{-1}\right)\end{array}$ & Country & References \\
\hline Baked Bricks & $\begin{array}{l}0.915 \pm 0.187 \\
\text { to } \\
1.909 \pm 0.269\end{array}$ & $\begin{array}{l}0.09 \\
0.215 \\
0.245-0.365 \\
0.212 \pm 0.034 \\
0.078-0.117\end{array}$ & $\begin{array}{l}\text { India } \\
\text { India } \\
\text { Pakistan } \\
\text { Pakistan } \\
\text { Algeria }\end{array}$ & $\begin{array}{l}\text { (Khan, 1994) } \\
\text { (Rawat et al., 1991) } \\
\text { (Rahman et al., 2007) } \\
\text { (Faheem and Matiullah, 2008) } \\
\text { (Amrani and Cherouati, 1999) }\end{array}$ \\
\hline Unbaked Bricks & $\begin{array}{l}1.068 \pm 0.202 \\
\text { to } \\
2.100 \pm 0.282\end{array}$ & $\begin{array}{l}0.11 \\
0.417\end{array}$ & $\begin{array}{l}\text { India } \\
\text { India }\end{array}$ & $\begin{array}{l}\text { (Khan, 1994) } \\
\text { (Rawat et al., 1991) }\end{array}$ \\
\hline Gray Cement & $\begin{array}{l}0.292 \pm 0.103 \\
\text { to } \\
0.438 \pm 0.126\end{array}$ & $\begin{array}{l}0.083-0.140 \\
0.231 \pm 0.030 \\
0.04\end{array}$ & $\begin{array}{l}\text { Algeria } \\
\text { Pakistan } \\
\text { India }\end{array}$ & $\begin{array}{l}\text { (Amrani and Cherouati, 1999) } \\
\text { (Faheem and Matiullah, 2008) } \\
\text { (Khan, 1994) }\end{array}$ \\
\hline White Cement & $0.0794 \pm 0.0212$ & ---- & ---- & ------- \\
\hline
\end{tabular}

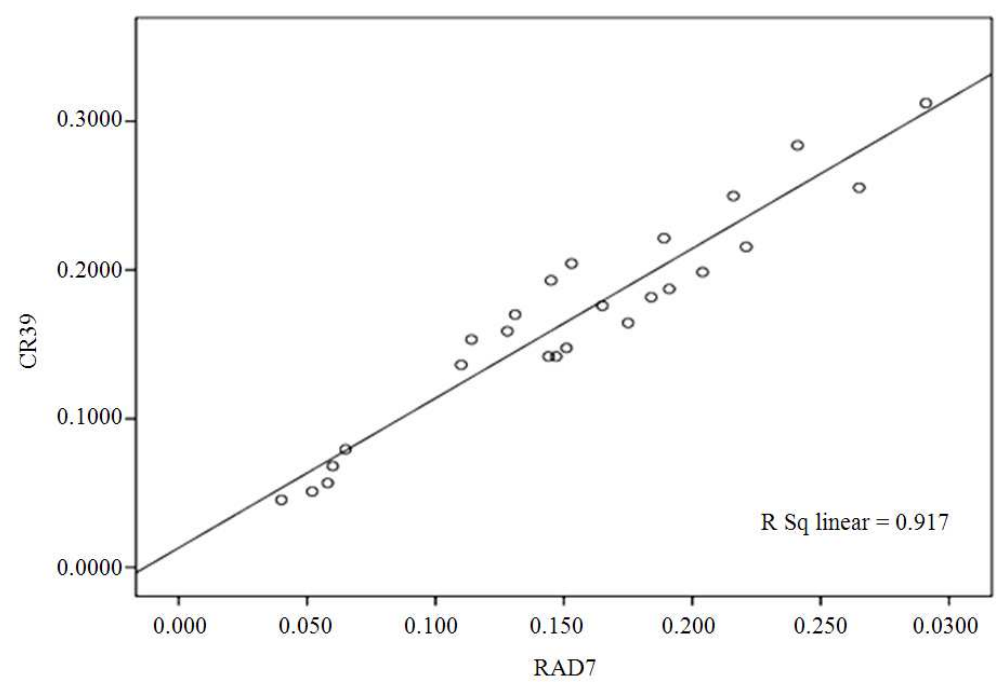

Fig. 2. Linearity between passive and active techniques for measurement of radon concentration 


\section{CONCLUSION}

Radiological parameters in building materials (bricks and cement) locally used in Dera Ismail Khan have been determined. Radon concentrations were measured by passive and active techniques and the results are in good agreement. Results obtained from the current study shows that the average radon exhalation rate $(1.419 \pm 0.230) \mathrm{Bq}$ $\mathrm{m}^{-2} \mathrm{~h}^{-1}$, radium activity $(1.13 \pm 0.184) \mathrm{Bq} / \mathrm{kg}$ and annual effective dose (40.35 \pm 6.51$) \mu \mathrm{Sv} \mathrm{y}^{-1}$ from unbaked bricks have comparatively higher values as compared to baked bricks (1.202 \pm 0.212$) \mathrm{Bq} \mathrm{m}^{-2} \mathrm{~h}^{-1},(0.956 \pm 0.169) \mathrm{Bq} / \mathrm{kg}$, (33.96 \pm 5.99$) \mu \mathrm{Sv} \mathrm{y}{ }^{-1}$ and cement $(0.386 \pm 0.117) \mathrm{Bq} \mathrm{m}^{-2}$ $\mathrm{h}^{-1}, \quad(0.323 \pm 0.098) \quad \mathrm{Bq} / \mathrm{kg}, \quad(10.94 \pm 3.28) \quad \mu \mathrm{Sv} \quad \mathrm{y}^{-1}$ respectively, but overall values of radon exhalation rate, radium activity and annual effective dose are below the world average value of $57.600 \mathrm{~Bq} \mathrm{~m}^{-2} \mathrm{~h}^{-1}$ (UNSCEAR, 2000), $370 \mathrm{~Bq} / \mathrm{kg}$ (OECD, 1979) and $1100 \mu \mathrm{Sv} \mathrm{y}{ }^{-1}$, respectively and thus are safe to be used as building materials according to the international recommendations. The values were found minimum for cement samples, therefore, from the health point of view it is suggested that cement houses are safer than mud houses. The present work was designed to study the radon level, radium activity and annual effective dose from building materials. Further studies are needed to determine radon level and natural radioactivity in water, soil, food and vegetation samples and their risk factors should be investigated.

\section{ACKNOWLEDGEMENT}

One of the researchers (Nisar Ahmad) is thankful to Universiti Sains Malaysia and TWAS for financial support in the form of TWAS-USM Fellowship.

\section{REFERENCES}

Abd-Elzaher, M., 2012. An overview on studying 222 rn exhalation rates using passive technique solid-state nuclear track detectors. Am. J. Applied Sci., 9: 1653-1659. DOI: 10.3844/ajassp.2012.1653.1659

Ackers, J.G., B.F.M. Bosnjakovic and L. Strackee, 1984. Limitation of radioactivity concentrations in building materials based on a practical calculation model. Radiat. Protect. Dosimetry, 7: 413-416.

Amrani, D. and D.E. Cherouati, 1999. Radon exhalation rate in building materials using plastic track detectors. J. Radioanalytical Nucl. Chem., 242: 269271. DOI: $10.1007 / \mathrm{BF} 02345552$
Cartwright, B.G., E.K. Shirk and P.B. Price, 1978. A nuclear-track-recording polymer of unique sensitivity and resolution. Nucl. Instruments Methods, 153: 457-460. DOI: 10.1016/0029554X(78)90989-8

Durrani, S.A. and R. Ilic, 1997. Radon Measurements by Etched Track Detectors: Applications in Radiation Protection, Earth Sciences and the Environment. 1st Edn., World Scientific Publishing, Singapure, ISBN-10: 9810226667, pp: 387.

Faheem, M. and Matiullah, 2008. Radon exhalation and its dependence on moisture content from samples of soil and building materials. Radiat. Measurem., 43: 1458-1462. DOI: 10.1016/j.radmeas.2008.02.023

Faheem, M., S.U. Rahman, T. Nasir, S. Rahman and Matiullah, 2010. Assessment of lung cancer risk using weighted average indoor radon levels in six districts of the Punjab Province in Pakistan. Indoor Built. Environ., 19: 382-390. DOI: 10.1177/1420326X10367311

Folkerts, K.H., G. Keller and H. Muth, 1984. An experimental study on diffusion and exhalation of ${ }^{222} \mathrm{Rn}$ and ${ }^{220} \mathrm{Rn}$ from building materials. Radiat. Protect. Dosim., 9: 27-34.

Henshaw, D.L., J.P. Eatough and R.B. Richardson, 1990. Radon as a causative factor in induction of myeloid leukaemia and other cancers. Lancet, 335: 10081012. DOI: 10.1016/0140-6736(90)91071-H

Howarth, C., J. Miles and G. Britain, 2002. Results of the 2001 NRPB intercomparison of passive radon detectors. National Radiological Protection Board.

IARC, 2004. IARC Monographs on the Evaluation of Carcinogenic Risks to Humans. 1st Edn., IARC Press, Lyon, France, ISBN-10: 9283212835, pp: 1452.

Ismail, A.H. and M.S. Jaafar, 2009. Experimental measurements on CR-39 response for radon gas and estimating the optimum dimensions of dosimeters for detection of radon. Proceedings of the 3rd Asian Physics Symposium, (APS' 09).

Khan, A., 1994. Estimation of dose rate for indoor radon from building materials. Radiat. Environ. Biophys., 33: 81-84. DOI: 10.1007/BF01255276

Nasir, T. and M. Shah, 2012. Measurement of annual effective doses of radon from drinking water and dwellings by CR-39 track detectors in kulachi city of Pakistan. J. Basic Applied Sci., 8: 528-536. 
Nasir, T. and N. Ahmad, 2012. The effect of grain size on radon exhalation rate in soil samples of dera ismail khan in pakistan. J. Basic Applied Sci., 8: 430-436.

OECD, 1979. Exposure to radiation from the natural radioactivity in building materials. Report by a Group of Experts of the OECD, Nuclear Energy Agency, Paris, France.

Rafique, M., S. Rahman, S. Rahman and T. Nasir, 2011a. Radiation doses due to indoor radon exposure, before and after the 2005 earthquake, in dwellings of muzaffarabad and the jhelum valley, Azad Kashmir, Pakistan. Indoor Built. Environ., 20: 259-264. DOI: 10.1177/1420326X10365809

Rafique, M., S.U. Rahman, T. Mahmood, S. Rahman and S.U. Rehman, 2011b. Radon exhalation rate from soil, sand, bricks and sedimentary samples collected from Azad Kashmir, Pakistan. Russian Geol. Geophys., 52: 450-457. DOI: 10.1016/j.rgg.2011.03.007

Rahman, S., F. Malik, T. Nasir and J. Anwar, 2012. Monitoring of Indoor radon levels around an oil refinery using CR-39-based radon detectors. Indoor Built. Environ., 21: 452-457. DOI: 10.1177/1420326X11410583

Rahman, S., N. Mati and B. Ghauri, 2007. Radon exhalation rate from the soil, sand and brick samples collected from NWFP and FATA, Pakistan. Radiat. Protect. Dosim., 124: 392-399. DOI: $10.1093 / \mathrm{rpd} / \mathrm{ncm} 226$
Ramachandran, T.V. and M.C.S. Ramu, 1989. Estimation of indoor radiation exposure from the natural radioactivity content of building materials. Oncology, 3: 20-25.

Rawat, A., P.J. Jojo, A.J. Khan, R.K. Tyagi and R. Prasad, 1991. Radon exhalation rate in building materials. Int. J. Radiat. Applic. Instrument. Part D. Nucl. Tracks Radiat. Measurements, 19: 391-394. DOI: 10.1016/1359-0189(91)90223-5

Shweikani, R., T. Giaddui and S. Durrani, 1995. The effect of soil parameters on the radon concentration values in the environment. Radiat. Measurem., 25: 581-584. DOI: 10.1016/1350-4487(95)00188-K

Somogyi, G., 1990. The environmental behaviour of radium.Tech. Rep. Series, 1: 229-256.

UNSCEAR, 2000. Report of the United Nations Scientific Committee on the Effects of Atomic Radiation to the General Assembly. ANNEX B Exposures from Natural Radiation Sources.

Wang, Z., 2002. Natural radiation environment in China. Int. Congress Series, 1225: 39-46. DOI: 10.1016/S0531-5131(01)00548-9 